http://dx.doi.org/10.1590/1678-4162-8453

Arq. Bras. Med. Vet. Zootec., v.69, n.2, p.317-324, 2017

\title{
Combinação de butafosfan e cianocobalamina no metabolismo da glicose em vacas leiteiras após o parto
}

\author{
[Combined of butaphosphan and cyanocobalamin on the glucose metabolism of \\ dairy cows after calving] \\ V.C. Tabeleão, E. Schwegler, R.A. Pereira, A.R.T. Krause, P. Montagner, J.O. Feijó, A. Schneider, \\ E. Schmitt, C.C. Brauner, V.R. Rabassa, F.A.B. Del Pino, M.N. Corrêa ${ }^{*}$ \\ Universidade Federal de Pelotas - Pelotas, RS
}

\begin{abstract}
The hypothesis of this study is that the combined use of butaphosphan and cyanocobalamin could enhance peripheral insulin resistance, increasing the amount of glucose available for the mammary gland and milk production. Thus, our aim was to investigate the combined effects of butaphosphan and cyanocobalamin on the glucose metabolism in dairy cows during the postpartum period. Twenty one dairy cows were divided into two groups: Control Group $(\mathrm{CON}, \mathrm{n}=11)$, that received 5 injections of saline solution $(20 \mathrm{~mL} /$ animal $0.9 \% \mathrm{NaCl})$, and Catosal group $(\mathrm{ABC}, \mathrm{n}=10)$ which received 5 injections of $20 \mathrm{~mL}$ of a Butafosfan and Cyanocobalamin solution (Catosal ${ }^{\mathbb{B}} \mathrm{B}_{12}, 100 \mathrm{mg}$ of Butafosfan and $50 \mu \mathrm{g}$ Cyanocobalamin for $\mathrm{mL}$ ). The injections were performed by intramuscular route, on days 7, 12, 17, 22 and 27 postpartum. Blood samples were taken on these days to evaluate plasma concentrations of phosphorus, glucose, non-esterified fatty acids (NEFA), albumin, aspartate aminotransferase (AST) and creatine kinase $(\mathrm{CK})$. On days 8 and 28 postpartum, the animals were weighted and subjected to the glucose tolerance and insulin challenge tests. The treatment promoted weight loss $(\mathrm{ABC} 40.4 \mathrm{~kg}, \mathrm{CON}$ $10.73 \mathrm{~kg}, \mathrm{P}<0.05)$ and increased AST (ABC $62.92 \pm 3.31 \mathrm{U} / \mathrm{L}, \mathrm{CON} 53.11 \pm 3.49 \mathrm{U} / \mathrm{L}, \mathrm{P}<0.05)$ and $\mathrm{CK}$ levels $(\mathrm{ABC} 134.09 \pm 19.08 \mathrm{U} / \mathrm{L}, \mathrm{CON} 79.43 \pm 18.27 \mathrm{U} / \mathrm{L}$ ). Glucose metabolism (area under the curve) did not differ ( $\mathrm{P}>0.05)$ among groups on days 8 and 28; however, $\mathrm{ABC}$ animals showed higher serum glucose levels $(\mathrm{P}<0.05)$ after insulin administration on day 28 postpartum $(97.54 \pm 8.54 \mathrm{mg} / \mathrm{dL})$ when compared to day $8(83.01 \pm 8.54 \mathrm{mg} / \mathrm{dL})$. It could be concluded that the combined use of butaphosphan and cyanocobalamin interferes positively with the adaptation of glucose metabolism in dairy cows in early lactation.
\end{abstract}

Keywords: energetic metabolism, organic phosphorus, insulin resistance, dairy cows

\section{RESUMO}

A hipótese deste estudo é de que o uso da combinação de butafosfan e cianocobalamina pode melhorar a resistência periférica à insulina, aumentar a quantidade de glicose disponível para a glândula mamária e a produção de leite. Assim, o objetivo foi investigar os efeitos combinados de butafosfan $e$ cianocobalamina sobre o metabolismo da glicose em vacas leiteiras no período pós-parto. Vinte e uma vacas leiteiras foram divididas em dois grupos: grupo controle $(C O N, n=11)$, que recebeu cinco aplicações de solução salina (20mL / animal 0,9\% NaCl), e grupo Catosal ${ }^{\circledR}(A B C, n=10)$, que recebeu cinco aplicações de 20mL de uma solução contendo as substâncias butafosfan e cianocobalamina (B12 Catosal ${ }^{\circledR}, 100 \mathrm{mg}$ da substância butafosfan e $50 \mu \mathrm{g}$ de cianocobalamina por $\mathrm{mL}$ ). As aplicações foram realizadas por via intramuscular, nos dias sete, 12, 17, 22 e 27 pós-parto. As amostras de sangue foram coletadas para a avaliação das concentrações plasmáticas de fósforo, glicose, ácidos graxos não esterificados (AGNE), albumina, aspartato aminotransferase (AST) e creatina quinase (CK). Nos dias oito e 28 pós-parto, os animais foram pesados e submetidos aos testes de tolerância à glicose e à

Recebido em 23 de maio de 2015

Aceito em 28 de junho de 2016

*Autor para correspondência (corresponding author)

E-mail: marcio.nunescorrea@gmail.com 
insulina. O tratamento promoveu perda de peso (ABC 40,4kg, CON 10,73kg, $P<0,05)$ e aumento da AST

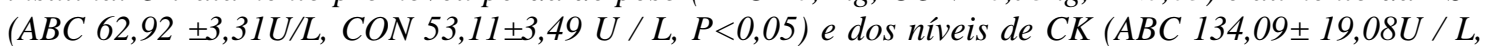
CON 79,43 $\pm 18,27 U / L$ ). Os grupos não diferiram quanto ao metabolismo (área sob a curva) da glicose nos dias oito e 28 , porém os animais tratados tiveram um aumento na glicemia $(P<0,05)$ no dia 28 pósparto $(97,54 \pm 8,54 \mathrm{mg} / \mathrm{dL})$, após a administração de insulina, em comparação ao dia oito (83,01 \pm $8,54 \mathrm{mg} / \mathrm{dL}$ ). Assim, pode-se concluir que a combinação de butafosfan e cianocobalamina melhora a adaptação do metabolismo da glicose em vacas leiteiras no início da lactação.

Palavras-chave: metabolismo energético, fósforo orgânico, resistência à insulina, vacas leiteiras

\section{INTRODUCTION}

The use of different strategies has contributed to the generation of dairy cows with higher production capacity, and, consequently, higher metabolic demands (Patton et al., 2007). These demands are mainly due to the synthesis of colostrum in the prepartum period as well as the synthesis of milk in the postpartum, causing metabolic changes in homeostatic and adaptive processes that characterize this transition period, in addition, low dry matter intake (DMI) increases negative energy balance (NEB) and then exacerbates metabolic alterations (Castaneda-Gutierrez et al., 2009).

Milk production, which increases in the first weeks postpartum, also increases the demand for glucose by the mammary gland, which requires $72 \mathrm{~g}$ glucose per liter of milk produced (Mattmiller et al., 2011). Some studies have demonstrated that milk production is positively correlated with peripheral insulin resistance, therefore the greater the genetic merit of the herd, the higher the milk production and the higher the insulin resistance and, therefore, the lower the glucose metabolism by peripheral tissues (Chagas et al., 2009, Zhang et al., 2013).

This peripheral insulin resistance is characterized by a decrease in the entry of glucose into the cell, which may be due to a lower expression of insulin receptors (Tsuruzoe et al., 2001) or to the lower insulin production by the pancreas (Ning et al., 2011). As a result, peripheral tissues use different compounds as energy sources, as the non-esterified fatty acids (NEFA), which are provided by adipose tissue (Ning et al., 2011) or amino acids arising from plasma and/or muscle proteins (De Koster and Opsomer, 2013) which are primarily intended for hepatic gluconeogenesis (Pires et al., 2013).
The combined use of butaphosphan, organic source of phosphorus, and cyanocobalamin, which contributes to the gluconeogenesis (Kreipe et al., 2011) has proven to have an effect on milk production and the NEB of cows (Pereira et al., 2013). Furthermore, this association decreases the expression of hepatic enzyme, which act on the metabolism of fatty acids, and increases the expression of the $\beta$-oxidation enzyme route (Kreipe et al., 2011). Therefore, the hypothesis of this study is that combined use of butaphosphan and cyanocobalamin could enhance peripheral insulin resistance, increase the amount of glucose available for the mammary gland and increase milk production. Therefore, the aim of this study was to investigate the combined effects of butaphosphan and cyanocobalamin on the glucose metabolism in dairy cows after calving.

\section{MATERIAL AND METHODS}

This study was approved by the Ethics Committee on Animal Experimentation at University Federal of Pelotas, registered under number 23110.

The experiment was conducted on a dairy farm in southern Brazil ( $\left.32^{\circ} 16^{\prime} \mathrm{S}, 5267^{\circ} 32^{\prime} \mathrm{E}\right)$ in a semi-extensive production system (pasture based with concentrate supplementation after milking). Twenty one Holstein dairy cows between 2 and 4 lactations and with no clinical signals of health disorders during previous lactation were divided into two groups: Control Group $(\mathrm{CON}, \mathrm{n}=11)$, that received 5 injections of saline solution $(20 \mathrm{~mL} /$ animal $0.9 \% \mathrm{NaCl})$, and Catosal group $(\mathrm{ABC}, \mathrm{n}=10)$ which received 5 injections of $20 \mathrm{~mL}$ of a solution of Butafosfan and Cyanocobalamin $\quad$ Catosal $^{\circledR} \quad \mathrm{B}_{12}, 100 \mathrm{mg}$ of Butafosfan and 50 $\mathrm{g}$ Cyanocobalamin for $\mathrm{mL}$ ). The injections were performed by intramuscular route, on days $7,12,17,22$ and 27 postpartum. The average weight of the selected cows at the 
beginning of the experiment was 588.43 $\pm 57.3 \mathrm{~kg}$. The body condition score (BCS) varied between 2 and 3.5 (7.14\% with score $2 ; 35.71 \%$ with score $2.5 ; 35.71 \%$ with score 3 , and $21.43 \%$ with score 3.5), on a scale of 1 to 5 (Wildman et al., 1982). The cows were milked twice a day (at 5a.m. and at 5p.m.). The ingredient composition of postpartum diets for dairy cows is observed in Tab. 1. Between the two milking procedures, cows had ad libitum access to water and pasture, which consisted of forage sorghum. Milk production was recorded daily by the ALPRO ${ }^{\circledR}$ Windows software (DeLaval, Kansas City, Mo, USA).

Table 1. Ingredient composition of postpartum diets for dairy cows

\begin{tabular}{lc}
\hline Ingredients & Amount $(\mathrm{kg})$ \\
\hline Forage sorghum & Ad libitum \\
Haylage & 15.000 \\
Wheatbran & 1.500 \\
Soybeanbran & 2.400 \\
Rice bran & 2.880 \\
Groundcorn & 3.000 \\
Groundsorghum & 2.130 \\
Mineral Supplements & 0.110 \\
Urea & 0.090 \\
Sodiumbicarbonate & 0.190 \\
Calciticlimestone & 0.190 \\
Salt & 0.002 \\
\hline
\end{tabular}

Blood samples were taken on days of treatment administration (days 7, 12, 17, 22 and 27 postpartum), after milking, before the injection and before feeding. Samples were placed into two tubes - tube 1, containing 10\% EDTA and glycolysis pathway inhibitor $(12 \%$ potassium fluoride), and tube 2 , containing only blood. The samples were then centrifuged at $1800 \mathrm{xg}$ for $15 \mathrm{~min}$ and frozen at $-20^{\circ} \mathrm{C}$ for subsequent biochemical analyzes, except glucose determination, which was done immediately.

The metabolites evaluated were plasma glucose, phosphorus, albumin, aspartate aminotransferase (AST) and creatine kinase (CK) by using commercial kits $\left(\right.$ Labtest $^{\circledR}$ Diagnóstica S.A., Brazil). The plasma concentration of nonesterified fatty acids (NEFA) was obtained by using a commercial kit (Wako NEFA-HR, Wako Chemicals, USA ${ }^{\circledR}$ ) and was performed according to the micromethod (Ballou et al., 2009) by using a plate reader (Thermo Plate ${ }^{\circledR}$ TP-Reader, São Paulo, Brazil): All the other metabolites were analyzed by colorimetric reaction by Visible Light Spectrophotometer (CELM SB 190 ${ }^{\circledR}$, CompanhiaEquipadora de LaboratóriosModernos - CELM, Brazil).

On days 8 and 28 postpartum, the animals were weighed and subjected to jugular vein catheterization immediately after milking and before feed supplementation in order to perform the glucose tolerance and insulin challenge tests. The glucose tolerance test was done by considering as a time zero the glucose infusion, and the glucose levels at $-5,0,15,30,45$ and 60 minutes after administration were used to determine the area under the curve (AUC).

To calculate the AUC for glucose, the area of the trapezoid formed between two subsequent samplings was used (Regnault et al., 2004), taking into consideration changes in relation to the baseline level of each individual (Area= (Value Collection 1 - Average of the two baseline collections + Value Collection 2 -Average of the two baseline collections) * Interval between collections/2). The glucose metabolic rate $(\delta)$ was defined as the speed of its metabolization (natural $\log \mathrm{iT}_{(15 \mathrm{~min})}$ - natural $\log \mathrm{fT}_{(60 \mathrm{~min})} / \mathrm{fTf}$ difference $\left._{(60 \mathrm{~min})}-\mathrm{iT}_{(15 \mathrm{~min})}\right) * 100$, where iT means initial time and fT means final time. The time required for glucose to reach half the initial concentration was defined as its half-life rate $\left(\mathrm{T}_{1 / 2 \mathrm{~min}}=100^{*}(0,693 / \delta)\right.$ (Chagas et al., 2009). Sixty minutes after glucose infusion, $0.1 \mathrm{UI} / \mathrm{kg}$ body weight insulin was applied, and the glucose disappearance rate was calculated by determining glycemia at 60, 65, 70, 75, 90, 120, 150 and $180 \mathrm{~min}$ after glucose infusion.

The data were analyzed by considering animals as experimental units. All variables were subjected to the test of normality by the ShapiroWilk test $(\mathrm{P}>0.90)$ through the UNIVARIATE Procedure. The variables were compared using the MIXED MODEL procedure, and the approach to determine the degrees of freedom in the denominator was performed by Satterthwaite for tests of fixed effects. The analyses of glucose application and the pre and post insulin application periods, serum, mean serum glucose, phosphorus, AST, CK and NEFA levels, body weight and milk production were compared between treatments, as well as the time of collection and their interaction (Littell et al., 1998) by means of analysis of variance 
with repeated measures. The autoregressive covariance structure provided the best fit for the analyses according to Akaike's information criterion. However, the first collection was considered as a covariate to make up for initial differences between treatments, being thus included in blood metabolite profiles in the statistical model, except for CK activity, which showed non normal distribution and was consequently analyzed by the nonparametric test by the NPAR1WAY procedure and a one-way classification. In addition, the animals were considered as random effects within treatments. The analyses of the half-life and metabolism rates, area under the curve of glucose and daily weight gain of the animals were individually compared between treatments by means of analysis of variance. The results were presented as mean \pm standard error of the mean (SEM). All statistical analyses were performed using the SAS software (Littell et al., 1998; SAS version 9.1- SAS ${ }^{\circledR}$ Institute Inc., Cary, NC, USA, 2009). Differences were considered significant when $\mathrm{P}<$ 0.05 .

\section{RESULTS}

The half-life, metabolism and AUC glucose rates, which were determined between 0 and 60 minutes $\left(\mathrm{GTT}_{0-60 \mathrm{~min},}\right.$ Tab. 2) on days 8 and 28 postpartum did not differ $(\mathrm{P}>0.05)$ between treatments. Nevertheless, the insulin challenge showed an interaction between group and collection $(\mathrm{P}=.02)$ in plasma glucose levels after insulin administration (between 60 and 180 minutes) in the $\mathrm{ABC}$ (Figure 1d); on day 8 postpartum, the mean glucose levels (83.01 $\pm 8.54 \mathrm{mg} / \mathrm{dL}$ ) were lower than those on day 28 postpartum $(97.54 \pm 8.54 \mathrm{mg} / \mathrm{dL})$. The trend, however, was not observed in the CON $(\mathrm{P}>0.05)$ (Figure 1b). In spite of this, mean plasma glucose levels did not differ between treatments and collections $(\mathrm{P}>0.05)$ on application days (Table 3). As to the period before insulin administration, no differences were observed between treatments, collections and their interactions $(\mathrm{P}>0.05)$ (Figure 1).

The body weight (Table 3 ) of the animals in the ABC was lower $(\mathrm{P}=0.0046)$ on day 28 , when compared to their weight on day 8. Also, differences between groups on day 28 were observed ( $\mathrm{P}=0.0433)$. Thus, the average daily weight gain $(\mathrm{kg})$ (Table 3$)$ was lower $(\mathrm{P}=0.0088)$ for $\mathrm{ABC}$ animals when compared to the CON. As to milk production (Table 3), differences between collections were observed $(\mathrm{P}=0.03)$, though there were no significant differences between groups, or in the group - collection interaction. Plasma levels of phosphorus, albumin and NEFA (Table 3) obtained during treatment did not differ $(\mathrm{P}>0.05)$ between groups, collections and their interactions. However, CK and AST activities were higher in the $\operatorname{ABC}(\mathrm{P}=0.04$ and $\mathrm{P}=0.05$, respectively) when compared to the $\mathrm{CON}$, but there were no significant differences between the collections and the group - collection interaction $(\mathrm{P}>0.05)$.

Table 2. Effects of the use of butaphosphan and cyanocobalamin combination on the glucose tolerance test (GTT0-60min), half-life rate, metabolism rate and area under the curve (AUC) of dairy cows

\begin{tabular}{|c|c|c|c|}
\hline \multirow[b]{2}{*}{ Parameters } & \multicolumn{2}{|c|}{ Treatment ${ }^{1}$} & \multirow[b]{2}{*}{$\mathrm{P}^{2}$} \\
\hline & $\mathrm{CON}^{1}$ & $\mathrm{ABC}^{2}$ & \\
\hline \multicolumn{4}{|l|}{ GTT D8 $8^{3}$} \\
\hline Glucose half-life rate $(\%)$ & $58.4 \pm 6.71$ & $61.9 \pm 7.04$ & 0.73 \\
\hline Metabolism rate $(\mathrm{min})$ & $1.3 \pm 0.14$ & $1.3 \pm 0.15$ & 0.95 \\
\hline Glucose $A U C^{5} 0-60 \mathrm{mg} / \mathrm{dL}$ & $7225.1 \pm 284.03$ & $6719.2 \pm 297.89$ & 0.23 \\
\hline \multicolumn{4}{|l|}{ GTT D28 } \\
\hline Glucose half-life rate $(\%)$ & $61.2 \pm 7.98$ & $64.9 \pm 8.37$ & 0.75 \\
\hline Metabolism rate $(\mathrm{min})$ & $1.3 \pm 0.19$ & $1.2 \pm 0.20$ & 0.61 \\
\hline Glucose $A U C^{5} 0-60 \mathrm{mg} / \mathrm{dL}$ & $7068.4 \pm 472.61$ & $6973.4 \pm 495.67$ & 0.89 \\
\hline
\end{tabular}


Table 3. Average daily weight gain (ADG) $(\mathrm{kg})$, milk production $(\mathrm{kg})$, blood concentration of NEFA $(\mathrm{mmol} / \mathrm{L})$, phosphorus $(\mathrm{mg} / \mathrm{dL})$, glucose $(\mathrm{mg} / \mathrm{dL})$, albumin $(\mathrm{g} / \mathrm{L})$, AST $(\mathrm{U} / \mathrm{L})$ and CK $(\mathrm{U} / \mathrm{L})$ of animals treated with butaphosphan and cyanocobalamin combination after calving

\begin{tabular}{|c|c|c|c|c|c|}
\hline \multirow{2}{*}{ Parameters } & \multicolumn{2}{|c|}{ Treatment $^{1}$} & \multicolumn{3}{|c|}{$\mathrm{P}^{2}$} \\
\hline & $\mathrm{COM}$ & $\mathrm{ABC}$ & Group & Collectic & p*Collection \\
\hline \multicolumn{6}{|l|}{ Performance } \\
\hline $\mathrm{ADG}^{3}(\mathrm{~kg})$ & $0.5^{\mathrm{b}} \pm 0.6$ & $-2.0^{\mathrm{a}} \pm 0.6$ & $<0.01$ & $\dagger$ & $\dagger$ \\
\hline Milkproduction (kg/day) & $24.5 \pm 2.0$ & $29.6 \pm 2.4$ & 0.13 & 0.03 & 0.54 \\
\hline \multicolumn{6}{|l|}{ Biochemical } \\
\hline $\mathrm{NEFA}^{4}(\mathrm{mmol} / \mathrm{L})$ & $0.2 \pm 0.04$ & $0.3 \pm 0.04$ & 0.16 & 0.15 & 0.51 \\
\hline Phosphorus (mg/dL) & $8.8 \pm 1.52$ & $7.5 \pm 2.14$ & 0.63 & 0.48 & 0.85 \\
\hline Glucose (mg/dL) & $68.1 \pm 6.10$ & $80.5 \pm 5.10$ & 0.14 & 0.27 & 0.43 \\
\hline Albumin $(g / L)$ & $21.0 \pm 1.4$ & $20.9 \pm 1.4$ & 0.33 & 0.13 & 0.44 \\
\hline Aspartate aminotransferase (U/L) & $53.1^{\mathrm{b}} \pm 3.49$ & $62.9^{\mathrm{a}} \pm 3.31$ & 0.05 & 0.16 & 0.97 \\
\hline Creatine kinase $(\mathrm{U} / \mathrm{L})$ & $79.4^{b} \pm 18.2$ & $134.1^{\mathrm{a}} \pm 19.1$ & 0.04 & $\dagger$ & $\dagger$ \\
\hline
\end{tabular}

GCon

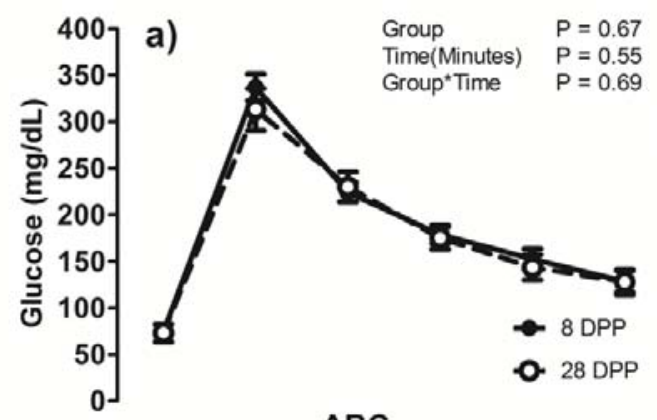

$\mathrm{ABC}$

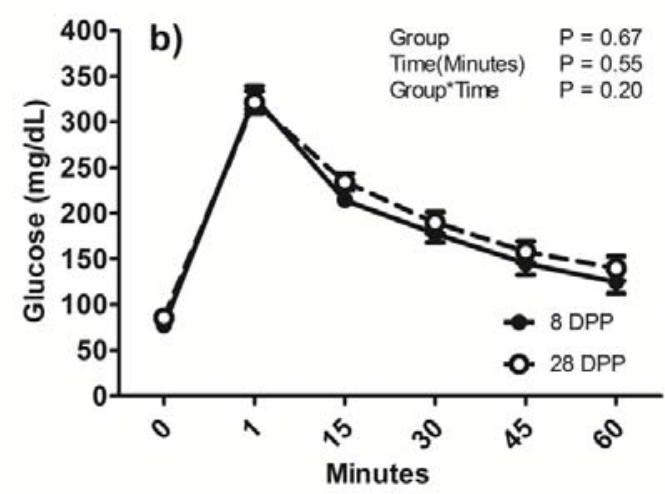

GCon

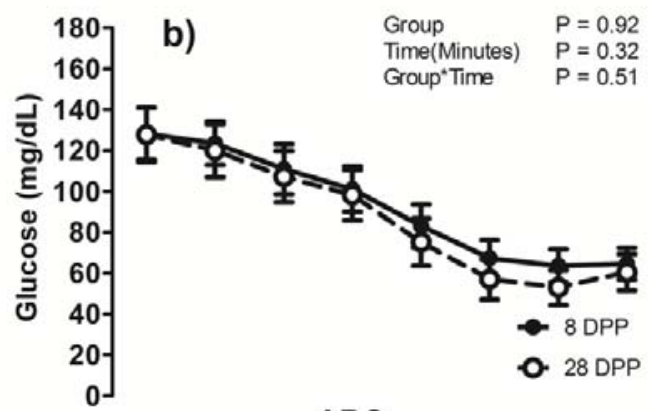

$\mathrm{ABC}$

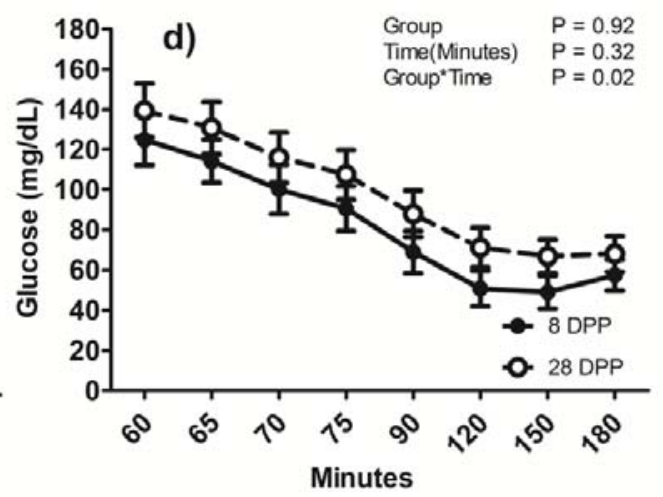

Figure 1:Mean plasma glucose levels $(\mathrm{mg} / \mathrm{dL})$ of dairy cows submitted to successive applications of butaphosphan and cyanocobalamine. Mean glucose levels in the control group (CON n=11; $\mathrm{NaCl} 0.9 \%$; $20 \mathrm{~mL}$ /animal) prior to insulin application (a); Mean plasma glucose levels ( $\mathrm{mg} / \mathrm{dL}$ ) in the catosal group $\left(\mathrm{ABC} \mathrm{n}=10 ; 20 \mathrm{~mL}\right.$ Catosal $^{\circledR} \mathrm{B}_{12}$ /animal perapplication) prior to insulin application (b); Mean plasma glucose levels $(\mathrm{mg} / \mathrm{dL})$ in the control group $(\mathrm{CON} \mathrm{n}=11 ; \mathrm{NaCl} 0.9 \% ; 20 \mathrm{~mL} /$ animal) after insulin injection (c); Mean plasma glucose levels $(\mathrm{mg} / \mathrm{dL})$ in the Catosal group $\left(\mathrm{ABC} n=10 ; 20 \mathrm{~mL}\right.$ Catosal $^{\circledR}$ $\mathrm{B}_{12}$ /animal per application) after insulin application (d). 


\section{DISCUSSION}

The higher $\mathrm{CK}(\mathrm{P}=0.04)$ and $\operatorname{AST}(\mathrm{P}=0.05)$ activities - the former muscle tissue specific and the latter found both in liver and muscle tissues (Shpigel et al., 2003) - observed in the ABC suggests greater muscle catabolism in the treated animals (Tab.3) as contrasted with the $\mathrm{CON}$, which gained weight during the experimental period. Still, a previous study investigating a similar treatment, found no changes in the muscle and lipid deposition of the animals, once the evaluation method used was BCS (Pereira et al., 2013). This methodology shows low sensitivity to detect small body weight variations, besides being subjective and demanding many observations (Loker et al., 2013, Pires et al., 2013).

Furthermore, the weight loss may result from a reduction in the glucose supply to the skeletal muscle due to a reduced expression of insulin receptors, which are necessary for the internalization of insulin through glucose transporter type 4 (GLUT4) (Duehlmeier et al., 2013, Zhang et al., 2013). This decrease in receptor expression has been demonstrated by other studies as being a physiological mechanism (Bell and Bauman, 1997, Kerestes et al., 2009) which aims to decrease glucose use by peripheral tissues and increase its availability to the mammary gland (Bell and Bauman, 1997, Mattmiller et al., 2011). This also increases the availability of amino acids for gluconeogenesis (Roche et al., 2009, Koster and Opsomer, 2013), promoting the conversion of methylmalonylCoA into succiny-CoA by methylmalonyl-CoA mutase, which is cyanocobalanin-dependent. This is an important route for the entry of propionate into the Krebs Cycle to synthesize energy (Furll et al., 2010). This adaptive mechanism (Roche et al., 2009) could be observed in the treated animals (Fig.1) which, after insulin administration, showed a decreased glucose metabolism at the end of the treatment (28 days postpartum) when compared to the beginning ( 8 days postpartum).

Therefore, the weight loss and muscle catabolism observed in $\mathrm{ABC}$ cows may be related to the high energy demand generated by an increased milk production (Roche et al., 2006, Chagas et al., 2009), which was $5.2 \mathrm{~kg}$ /day higher for the $\mathrm{ABC}$ animals (Table 3). This may have resulted from the synthesis of lactose, which occurs from glucose. The former is responsible for $50 \%$ of the osmotic pressure, partially determining the milk volume (Boutinaud et al., 2008). Besides, this was not the central hypothesis of this study, other authors have already demonstrated an increase in the production of dairy cows supplemented with 5 doses of $1000 \mathrm{mg}$ butaphosphan and $0.5 \mathrm{mg}$ cyanocobalamin (Pereira et al., 2013), or 3 doses of $10 \mathrm{mg}$ butaphosphan and $0.05 \mathrm{mg}$ cyanocobalamin $/ \mathrm{kg}$ body weight (Kreipe et al., 2011).

No differences were detected in $\mathrm{GTT}_{0-60 \mathrm{~min}}$ halflife and glucose degradation rates and area under the curve (Tab. 2). These results suggest that the homeostatic mechanisms of glucose metabolism, which are mediated by endogenous insulin (Balogh et al., 2009) were not altered by the successive associated doses of butaphosphan and cyanocobalamin, thus keeping a constant transport speed of plasma into the cells (Duehlmeier et al., 2013).

Similarly, plasma levels of the other metabolites evaluated were not altered by supplementation. This can be attributed to either the low butaphosphan plasma half-life, once it can be detected in the urine flow 116 minutes after intravenous application (Veterinary..., 2000) or to its use in the phosphorylation of proteins that act on energy metabolism pathways (Grunberg et al., 2009). The same trend was observed for albumin levels, thus demonstrating that the hepatic conditions of protein anabolism and catabolism, as well as the supply of dietary protein (Raggio et al., 2007), were similar for both groups, being suitable for the transition period but lower than those of cows over 100 days of lactation (Alberghina et al., 2011). Likewise, NEFA, which measures the intensity of lipolysis in the adipose tissue (Patton et al., 2007, Rocco and McNamara, 2013), showed molar equivalence between groups, signaling that there were no lipolysis differences between treatments.

\section{CONCLUSIONS}

Combined use of butaphosphan and cyanocobalamin has the ability to enhance the adaptive physiological processes of the glucose metabolism, as well as influence the rate of muscle protein metabolism in dairy cows, which 
integrate the transition period. In summary, the metaphylatic injection of butaphosphan and cyanocobalamine interferes in the glucosemetabolism in dairy cows during the negative energy balance period.

\section{ACKNOWLEDGMENTS}

The authors thank Coordenação de Aperfeiçoamento de Pessoal de Nível Superior (CAPES) and Conselho Nacional de Desenvolvimento Científico e Tecnológico (CNPq) for the financial support.

\section{REFERENCES}

ALBERGHINA, D.; GIANNETTO, C.; VAZZANA, I. et al. Reference intervals for total protein concentration, serum protein fractions, and albumin/globulin ratios in clinically healthy dairy cows. J. Vet. Diagn. Investig., v.23, p.111114, 2011.

BALLOU, M.A.; GOMES, R.C.; JUCHEM, S.O.; DEPETERS, E.J. Effects of dietary supplemental fish oil during the peripartum period on blood metabolites and hepatic fatty acid compositions and total triacylglycerol concentrations of multiparous. J. Dairy Sci., v.92, p.657-669, 2009.

BALOGH, O.; KOVACS, K.; KULCSAR, M. et al. AluI polymorphism of the bovine growth hormone $(\mathrm{GH})$ gene, resumption of ovarian cyclicity, milk production and loss of body condition at the onset of lactation in dairy cows. Theriogenology, v.71, p.553-559, 2009.

BELL, A.W.; BAUMAN, D.E. Adaptations of glucose metabolism during pregnancy and lactation. J. Mammary Gland Biol. Neoplasia, v.2, p.265-278, 1997.

BOUTINAUD, M.; BEN CHEDLY, M.H.; DELAMAIRE，E.; GUINARD-FLAMENT，J. Milking and feed restriction regulate transcripts of mammary epithelial cells purified from milk. J. Dairy Sci., v.91, p.988-998, 2008.

CASTANEDA-GUTIERREZ， E.; PELTON, S.H.; GILBERT, R.O.; BUTLER, W.R. Effect of peripartum dietary energy supplementation of dairy cows on metabolites, liver function and reproductive variables. Anim. Reprod. Sci., v.112, p.301-315, 2009.
CHAGAS, L.M.; LUCY, M.C.; BACK, P.J. et al. Insulin resistance in divergent strains of holstein-friesian dairy cows offered fresh pasture and increasing amounts of concentrate in early lactation. J. Dairy Sci., v.92, p.216-222, 2009.

DUEHLMEIER, R.; NOLDT, S.; GANTER, M. Pancreatic insulin release and peripheral insulin sensitivity in german black headed mutton and finish landrace ewes: evaluation of the role of insulin resistance in the susceptibility to ovine pregnancy toxemia. Domest. Anim. Endocrinol., v.44, p.213-221, 2013.

FURLL, M.; DENIZ, A.; WESTPHAL, B. et al. Effect of multiple intravenous injections of butaphosphan and cyanocobalamin on the metabolism of periparturient dairy cows. J. Dairy Sci., v.93, p.4155-4164, 2010.

GRUNBERG, W.; STAUFENBIEL, R.; CONSTABLE, P.D. et al. Liver phosphorus content in holstein-friesian cows during the transition period. J. Dairy Sci., v.92, p.21062117, 2009.

KERESTES, M.; FAIGL, V.; KULCSAR, A. et al. Periparturient insulin secretion and wholebody insulin responsiveness in dairy cows showing various forms of ketone pattern with or without puerperal metritis. Domest. Anim. Endocrinol., v.37, p.250-261, 2009.

KOSTER, J.D.; OPSOMER, G. Insulin resistance in dairy cows. Vet. Clin. N. Am. Small Anim. Pract., v.29, p.299-322, 2013.

KREIPE, L.; DENIZ, A.; BRUCKMAIER, R.M.; VAN DORLAND, H.A. First report about the mode of action of combined butafosfan and cyanocobalamin on hepatic metabolism in nonketotic early lactating cows. J. Dairy Sci.,v.94, p.4904-4914, 2011.

LITTELL, R.C.; HENRY, P.R.; AMMERMAN, C.B. Statistical analysis of repeated measures data using SAS procedures. J. Anim. Sci., v.76, p.1216-1231, 1998.

LOKER, S.; BASTIN, C.; MIGLIOR, F. et al. Development of a genetic evaluation for body condition score for Canadian Holsteins. J. Dairy Sci., v.96, p.3994-4004, 2013. 
MATTMILLER, S.A.; CORL, C.M.; GANDY, J.C. et al. Glucose transporter and hypoxiaassociated gene expression in the mammary gland of transition dairy cattle. J. Dairy Sci., v.94, p.2912-2922, 2011.

NING, J.; HONG, T.; YANG, X. et al. Insulin and insulin signaling play a critical role in fat induction of insulin resistance in mouse. Am. J. Physiol. Endocrinol. Metab., v.301, p.391-401, 2011.

PATTON, J.; KENNY, D.A.; MCNAMARA, S. et al. Relationships among milk production, energy balance, plasma analytes, and reproduction in holstein-friesian cows. J. Dairy Sci., v.90, p.649-658, 2007.

PEREIRA, R.A.; SILVEIRA, P.A.S.; MONTAGNER, P. et al. Effect of butaphosphan and cyanocobalamin on postpartum metabolism and milk production in dairy cows. Animal, v.7, p.1143-1147, 2013.

PIRES, J.A.A.; DELAVAUD, C.; FAULCONNIER, Y. et al. Effects of body condition score at calving on indicators of fat and protein mobilization of periparturient holsteinfriesian cows. J. Dairy Sci., v.96, p.6423-6439, 2013.

RAGGIO, G.; LOBLEY, G.E.; BERTHIAUME, R. et al. Effect of protein supply on hepatic synthesis of plasma and constitutive proteins in lactating dairy cows. J. Dairy Sci., v.90, p.352$359,2007$.

REGNAULT, T.R.; ODDY, H.V.; NANCARROW, C. et al. Glucose-stimulated insulin response in pregnant sheep following acute suppression of plasma non-esterified fatty acid concentrations. Reprod. Biol. Endocrinol., v.2, p.64, 2004.

ROCCO, S.M.; MCNAMARA, J.R. Regulation of bovine adipose tissue metabolism during lactation. 7. Metabolism and gene expression as a function of genetic merit and dietary energy intake. J. Dairy Sci., v.96, p.3108-3119, 2013
ROCHE, J.R.; BERRY, D.P.; KOLVER, E.S. Holstein-friesian strain and feed effects on milk production, body weight, and body condition score profiles in grazing dairy cows. J. Dairy Sci., v.89, p.3532-3543, 2006.

ROCHE, J.R.; FRIGGENS, N.C.; KAY, J.K. et al. Invited review: body condition score and its association with dairy cow productivity, health, and welfare. J. Dairy Sci., v.92, p.5769-5801, 2009.

SHPIGEL, N.Y.; AVIDAR, Y.; BOGIN, E. Value of measurements of the serum activities of creatine phosphokinase, aspartate aminotransferase and lactate dehydrogenase for predicting whether recumbent dairy cows will recover. Vet. Rec., v.152, p.773-776, 2003.

STATISTICAL analysis system. version 9.1. SAS ${ }^{\circledR}$ Institute Inc., Cary, NC, USA, 2009.

TSURUZOE, K.; EMKEY, R.; KRIAUCIUNAS, K.M. et al. Insulin receptor substrate 3 (IRS-3) and IRS-4 impair IRS-1- and IRS-2-mediated signaling. Mol. Cell Biol., v.21, p.26-38, 2001.

VETERINARY medicines and information technology unit. London: EMEA, 2000. p.1-2. (EMEA/MRL/734/00-FINAL).

WILDMAN, E.E.; JONES, G.M.; WAGNER, P.E. et al. A dairy-cow body condition scoring system and Its relationship to selected production characteristics. J. Dairy Sci., v.65, p.495-501, 1982.

ZHANG, Z.G.; WANG, J.G.; GAO, R.F. et al. High-energy diet at antepartum decreases insulin receptor gene expression in adipose tissue of postpartum dairy cows. Bull. Vet. Inst. Pulawy, v.57, p.203-207, 2013. 